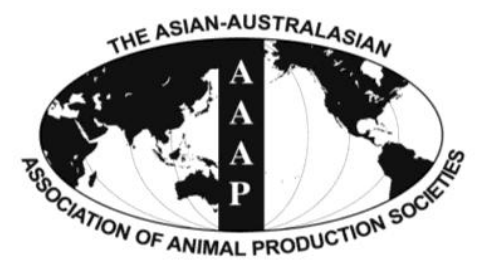

Asian-Aust. J. Anim. Sci.

Vol. 25, No. $8: 1124$ - 1131

August 2012

www.ajas.info

http://dx.doi.org/10.5713/ajas.2012.12109

\title{
Effect of Ground Corn Cob Replacement for Cassava Chip on Feed Intake, Rumen Fermentation and Urinary Derivatives in Swamp Buffaloes
}

\author{
M. Wanapat*, R. Pilajun, S. Kang, K. Setyaningsih and A. R. Setyawan \\ Tropical Feed Resources Research and Development Center (TROFREC), Department of Animal Science, \\ Faculty of Agriculture, Khon Kaen University, Khon Kaen 40002, Thailand
}

\begin{abstract}
Four Thai - rumen fistulated male swamp buffaloes (Bubalus bubalis), about four years old with $400 \pm 20 \mathrm{~kg}$ liveweight, were randomly assigned according to a $4 \times 4$ Latin square design to receive dietary treatments. The treatments were: ground corn cob (GCC) replacement for cassava chip (CC) in concentrate at 0\% (T1); GCC replacement at 33\% (T2); GCC replacement at 67\% (T3); and GCC replacement at $100 \%$ (T4), respectively. During the experiment, concentrate was offered at $0.5 \%$ BW while 5\% urea-treated rice straw was given at ad libitum. The result revealed that there was no effect of GCC replacement on DMI among treatments. In addition, digestibilities of DM, OM and CP were not different while aNDF linearly increased with an increasing level of GCC replacement. However, GCC replacement did not affect rumen fermentation such as ruminal $\mathrm{pH}, \mathrm{NH}_{3}-\mathrm{N}$ and VFA concentration; except $\mathrm{C} 3$ proportion which was the highest at 33\% replacement while the lowest was at $100 \%$ replacement. All replacements of GCC resulted in similar protozoal and bacterial populations and microbial protein synthesis (MPS). Purine derivatives (PD) concentration in urine and $\mathrm{PD}$ to creatinine (PDC) index were varied with time of urination and among treatments at 0 to 8 and 8 to $16 \mathrm{~h}$ post feeding and higher values were shown among the GCC replacement groups. However at 16 to 24 h-post feeding, it was untraceable. In addition, creatinine concentration was similar among all treatments at every sampling time. Based on the above results, GCC can be used as an energy source for swamp buffalo fed with rice straw. Spot sampling of urine can be used for purine derivatives determination. (Key Words: Corn Cob, Cassava Chip, Rumen Ecology, Purine Derivatives, Swamp Buffalo, Rice Straw)
\end{abstract}

\section{INTRODUCTION}

Ruminants raised in the tropics largely depend on seasonal feed resources which are relatively low in quality in terms of low CP but high in structural carbohydrate (SC); hence, the manipulation of rumen efficiency through the use of local feed resources would be an advantage (Wanapat, 2000). Due to the low quality of roughages, supplementation with a concentrate diet containing a high density of energy and nitrogen would be potentially useful and could be prepared on farms (Wanapat, 1999). Cassava (Manihot esculenta, Crantz) is one of an important cash crop widely grown in sandy loam soils receiving low fertilizer application in the dry season. Cassava root production in tropical areas has a potential for increased use in ruminant nutrition as it contains high levels of energy and

\footnotetext{
* Corresponding Author: M. Wanapat. Tel: +66-4320-2368, Fax: +66-4320-2368, E-mail: metha@kku.ac.th Submitted Feb. 28, 2012; Accepted Apr. 24, 2012; Revised May 7, 2012
}

has been used as an energy source in ruminant diets (Wanapat et al., 2003; Kiyothong and Wanapat, 2004; Promkot and Wanapat, 2005). However, the utilization of cassava as an energy source in animal feed is competitive with other functional uses including potential use for biofuel production. Corn cob is another crop residue that can be used as an energy source in ruminant feeding (Wanapat and Rowlinson, 2007). In addition, it has been shown that corn cob can be used as a non forage fiber source, which resulted in increasing milk fat concentration and decreasing rumination time when compared with a high alfalfa diet in dairy cattle (Depies and Armentano, 1995). According to Fries et al. (1955), corn cob could be used as satisfactory roughage for growing heifers and was an alternative roughage source in lactating dairy cows fed on restricted roughage rations. Moreover, corn cob, either ground cob or ground ear corn, has been used as an energy source in concentrate mixtures for dairy cows (Peyton and Conrad, 1982). Most recently, Wanapat et al. (2009a) 
recommended that corn cob could be efficiently utilized in the rumen and thus could provide good fermentation endproducts which resulted in a remarkable count of viable bacteria in the buffalo rumen especially the cellulolytic bacteria as compared buffalo fed cassava chip as their energy source.

On the other hand, microbial protein has been shown to significantly supply amino acids for digestion and absorption in the lower gut (Dewhurst et al., 2000). Based on that, there have been numerous studies which have attempted to determine the extent and efficiency of rumen MPS in various target species (Siddons et al., 1985; Broderick and Merchen, 1992). However, all of methods are inconvenient as they require a total collection of urine for analysis (Chen and Gomes, 1992). As an alternative to total urine collection, Cetinkaya et al. (2006) and Chizzotti et al. (2008) have proposed a spot sampling technique to assess the excretion of urinary nitrogenous compounds. The PD:creatinine concentration ratio in the spot urine sample is a good indicator of the daily urinary PD excretion unless the daily creatinine excretion is known (Valadares et al., 1999). Pimpa et al. (2003) have developed a methodology for estimation MPS in the rumen of swamp buffalo using purine derivative excretion. However, the accuracy of estimating PD by using spot urine sampling has not been established in swamp buffaloes.

Therefore, the aims of this study were to determine the effect of replacing cassava chips with corn cob in concentrate on feed intake, nutrient digestibility, rumen fermentation and microbial protein synthesis in swamp buffaloes fed on urea-treated rice straw.

\section{MATERIALS AND METHODS}

\section{Animals, feeds and experimental design}

Four Thai - rumen fistulated male swamp buffaloes (Bubalus bubalis), about 4 years old with $400 \pm 20 \mathrm{~kg}$ liveweight, were randomly assigned according to a $4 \times 4$ Latin square design to receive four dietary treatments. The dietary treatments (T) were ground corn cob (GCC) replacement for cassava chip (CC) in concentrate at four levels. The treatments were as follows: GCC replacement at $0 \%$ (T1); GCC replacement at 33\% (T2); GCC replacement at 67\% (T3); and GCC replacement at 100\% (T4), respectively. Four periods were conducted throughout the whole experiment and each period lasted for 21 days, during the first 14 days straw intake was measured, while during the last 7 days of each period the animals were held in metabolism crates for the total collection of feces and urine. The feed ingredients and chemical composition of concentrate and 5\% urea treated rice straw (UTR) are presented in Table 1. Animals were supplemented with respective concentrate at $0.5 \% \mathrm{BW}$ two times per day (07:00 am and 04:00 pm) and UTS was given ad libitum. Mineral block and fresh water were available as free choice for all animals in individual pens.

\section{Data collection and chemical analysis}

Feed offered and refusals were recorded daily throughout the experimental period for DM intake (DMI)

Table 1. Ingredients and chemical composition of concentrate mixture used in the experiment

\begin{tabular}{|c|c|c|c|c|c|c|c|}
\hline \multirow{2}{*}{ Ingredients } & \multicolumn{4}{|c|}{ Ground corn cob replacement (\%) } & \multirow{2}{*}{$\begin{array}{c}\text { Cassava } \\
\text { chip }\end{array}$} & \multirow{2}{*}{$\begin{array}{l}\text { Ground corn } \\
\text { cob }\end{array}$} & \multirow{2}{*}{$\begin{array}{l}\text { Urea treated } \\
\text { rice straw }\end{array}$} \\
\hline & 0 & 33 & 67 & 100 & & & \\
\hline Cassava chip & 65.8 & 44.1 & 21.7 & 0.0 & & & \\
\hline Ground corn cob & 0.0 & 21.7 & 44.1 & 65.8 & & & \\
\hline Rice bran & 6.0 & 7.9 & 7.4 & 6.1 & & & \\
\hline Brewery's grain & 12.8 & 11.5 & 11.0 & 10.5 & & & \\
\hline Palm seed meal & 10.1 & 8.0 & 8.0 & 7.3 & & & \\
\hline Urea & 2.0 & 2.0 & 2.0 & 2.0 & & & \\
\hline Molasses & 1.0 & 2.0 & 2.5 & 3.5 & & & \\
\hline Tallow & 0.5 & 1.0 & 1.5 & 2.0 & & & \\
\hline Sulphur & 0.3 & 0.3 & 0.3 & 0.3 & & & \\
\hline Salt & 0.5 & 0.5 & 0.5 & 0.5 & & & \\
\hline Mineral mix & 1.0 & 1.0 & 1.0 & 1.0 & & & \\
\hline \multicolumn{8}{|c|}{ Chemical composition } \\
\hline $\mathrm{DM}(\%)$ & 91.5 & 91.1 & 90.4 & 90.8 & 65.5 & 88.9 & 90.3 \\
\hline $\mathrm{OM}$ & 94.0 & 94.2 & 94.0 & 93.7 & 81.7 & 88.7 & 87.5 \\
\hline $\mathrm{CP}$ & 12.0 & 12.0 & 12.0 & 12.1 & 6.8 & 2.5 & 3.1 \\
\hline aNDF & 16.1 & 33.3 & 50.9 & 68.1 & 72.3 & 50.2 & 67.9 \\
\hline $\mathrm{ADF}$ & 8.8 & 15.3 & 21.9 & 28.5 & 50.3 & 43.6 & 48.5 \\
\hline Ash & 6.0 & 5.8 & 6.0 & 7.3 & 18.3 & 11.3 & 12.5 \\
\hline
\end{tabular}

$\mathrm{DM}=$ Dry matter, $\mathrm{OM}=$ Oganic matter, $\mathrm{CP}=$ Crude protein, $\mathrm{aNDF}=$ Neutral detergent fiber, $\mathrm{ADF}=\mathrm{Acid}$ detergent fiber. 
calculation and feed samples were randomly collected twice a week for DM analysis. Samples of concentrate mixture, UTR including refusals and feces (5\% of sub-sample; Singh et al., 2007) were collected daily during the collection period. Samples of UTR, concentrate mixtures and feces were composited by period and stored at $-20^{\circ} \mathrm{C}$ for later chemical analyses. The samples were divided into two parts, first part was for DM analyses, while the second part was kept and pooled at the end of each period for analyses of Ash, CP, aNDF and ADF. Feeds, refusals and fecal samples were dried at $60^{\circ} \mathrm{C}$ and ground $(1 \mathrm{~mm}$ screen using the Cyclotech Mill, Tecator, Sweden) and analyzed using standard methods of AOAC (1995) for DM (ID 967.03) and ash (ID 942.05). Acid detergent fiber was determined according to an AOAC method (1995; ID 973.18) and was expressed inclusive of residual ash. The aNDF in samples was estimated according to Van Soest et al. (1991) with the addition of $\alpha$-amylase but without sodium sulphite and results were expressed with residual ash. Total nitrogen $(\mathrm{N})$ was determined according to AOAC (1995; ID 984.13).

Rumen $\mathrm{pH}$ and fermentation characteristics were measured and collected at the last day of each period post morning feeding. Approximate $200 \mathrm{ml}$ of rumen fluid were taken from the middle part of the rumen using a $60 \mathrm{ml}$ hand syringe. Rumen fluid was immediately measured for $\mathrm{pH}$ using a portable $\mathrm{pH}$ temperature meter (Hanna Instruments HI 8424 microcomputer, Singapore) and the fluid samples were then strained through four layers of cheesecloth and divided into three parts. The first $45 \mathrm{ml}$ of the rumen fluid sample was collected and kept in a plastic bottle to which 5 $\mathrm{ml}$ of $1 \mathrm{M} \mathrm{H}_{2} \mathrm{SO}_{4}$ was added to stop the fermentation process and then centrifuged at $3,000 \times g$ for $10 \mathrm{~min}$. About 20 to $30 \mathrm{ml}$ of supernatant was collected and analyzed for $\mathrm{NH}_{3}-\mathrm{N}$ by Kjeltech Auto 1030 Analyzer (AOAC, 1995; ID 973.18) and VFA using High Pressure Liquid Chromatography (HPLC, Instruments by Water and Novapak model 600E; water mode 1484 UV detector; column novapak C18; column size $3.9 \mathrm{~mm} \times 300 \mathrm{~mm}$; mobile phase $10 \mathrm{mM} \mathrm{H}_{2} \mathrm{PO}_{4}$ (pH 2.5)) according to Samuel et al. (1997). The second portion of $1 \mathrm{ml}$ rumen fluid was collected and kept in a plastic bottle to which $9 \mathrm{ml}$ of 10 $\mathrm{ml} / \mathrm{l}$ formalin solution $(1: 9 \mathrm{v} / \mathrm{v}$, rumen fluid: $10 \mathrm{ml} / \mathrm{L}$ formalin) was added and stored at $4{ }^{\circ} \mathrm{C}$ for measuring protozoal population using total direction counts by the methods of Galyean (1989) with a haemacytometer (Boeco, Singapore). The third portion was for the total viable bacteria count (cellulolytic, proteolytic, amylolytic and total viable bacteria) using the Hungate (1969) roll-tube technique. Total viable counts of bacteria were determined in roll tubes on a complete agar medium (Hobson, 1969) while the numbers of cellulolytic bacteria were estimated as the most probable number in agar (Hobson, 1969). In addition, while proteolytic bacteria were determined in a casein medium, amylolytic bacteria were estimated in a starch medium (Hobson, 1969). Culture methods were based on those described by Hungate (1969).

Total urine excretion was collected and acidified to $\mathrm{pH}$ 2 using $\mathrm{H}_{2} \mathrm{SO}_{4}$ solution (2 M). Urine samples were analyzed for allantoin concentration by HPLC as described by Chen et al. (1993). Moreover, spot urine was collected manually at every time of urination and analyzed for allantoin (IAEA, 1997) and creatinine (Hawk et al., 1976). The supply of microbial $\mathrm{N}(\mathrm{MN})$ was estimated by the urinary excretion of purine derivatives (PD) according to Chen and Gomes (1995):

$$
\mathrm{Y}=0.85 \mathrm{X}+\left(0.385 \mathrm{BW}^{0.75}\right)
$$

$\mathrm{MN}(\mathrm{g} / \mathrm{d})=70 \mathrm{X} /(0.116 \times 0.83 \times 1,000)=0.727 \mathrm{X}$; where $\mathrm{X}$ and $\mathrm{Y}$ are the absorption and excretion of $\mathrm{PD}$ in $\mathrm{mmol} / \mathrm{d}$, respectively.

Efficiency of microbial $\mathrm{N}$ supply (EMNS) was calculated using the following formula:

\section{$\mathrm{EMNS}=\mathrm{MN}(\mathrm{g} / \mathrm{d}) / \mathrm{DOMR}$}

where DOMR = digestible OM apparently fermented in the rumen (assuming that rumen digestion was $65 \%$ of $\mathrm{OM}$ digestion in total tract, $\mathrm{DOMR}=\mathrm{DOMI} \times 0.65 ; \mathrm{DOMI}=$ digestible OM intake).

For spot urine samples, since the daily creatinine excretion is a function of body weight, Chen et al. (2004) suggested using a term "PDC index" which is corrected for metabolic weight. Hence, the following equation was proposed to calculate PDC index:

$\mathrm{Y}=\mathrm{aX}$; where $\mathrm{Y}$ is $\mathrm{PDC}$ index $(\mathrm{kg})$, $\mathrm{a}$ is $\mathrm{PD}$ to creatinine ratio, $\mathrm{X}$ is metabolic body weight $(\mathrm{kg})$. PD and creatinine concentrations are in urine in $\mathrm{mmol} / \mathrm{L}$.

\section{Statistical analysis}

All data were subjected to analysis of variance using GLM procedure according to the model $\mathrm{Y} i j k=\mu+\mathrm{A}_{i}+\mathrm{P}_{j}+\mathrm{T}_{k}$ + eijk where Yijk observation from animal $i$, in period $j$ and receiving diet $k ; \mu$, the overall of mean, $\mathrm{A}_{i}$, the effect of animal ( $i=1$ to 4 ), $\mathrm{P}_{j}$, the effect of period ( $j=1$ to 4 ), $\mathrm{T}_{k}$, the effect of level GCC replacement ( $k=1$ to 4$)$, eijk the residual effect. Mean separations with a significant $F$ $(\mathrm{p}<0.05)$ and treatment means were statistically compared using orthogonal polynomial of SAS (1996).

\section{RESULTS}

\section{Chemical compositions of diet}

Experimental feeds and their chemical composition are shown in Table 1. The mixture of concentrate, consisting of available local feed resources such as energy source (CC 
Table 2. Effect of the replacement of cassava chip by ground corn cob on total feed intake and digestibility

\begin{tabular}{|c|c|c|c|c|c|c|c|c|}
\hline & \multicolumn{4}{|c|}{ Ground corn cob replacement (\%) } & \multirow{2}{*}{ SEM } & \multicolumn{3}{|c|}{ Contrast $^{1}$} \\
\hline & 0 & 33 & 67 & 100 & & $\mathrm{~L}$ & Q & $\mathrm{C}$ \\
\hline \multicolumn{9}{|l|}{ DM intake (kg/d) } \\
\hline Treated rice straw & 6.36 & 6.71 & 6.54 & 6.29 & 0.22 & ns & ns & ns \\
\hline Concentrate & 2.17 & 2.19 & 2.17 & 1.94 & 0.09 & ns & 0.07 & ns \\
\hline \multicolumn{9}{|l|}{ Total intake } \\
\hline $\mathrm{kg}$ & 8.53 & 8.90 & 8.71 & 8.23 & 0.21 & ns & 0.09 & ns \\
\hline $\mathrm{g} / \mathrm{kg} \mathrm{BW}$ & 196 & 199 & 191 & 190 & 0.80 & ns & ns & ns \\
\hline $\mathrm{g} / \mathrm{kg} \mathrm{BW}^{0.75}$ & 89.55 & 91.53 & 88.10 & 86.61 & 3.25 & ns & $\mathrm{ns}$ & ns \\
\hline \multicolumn{9}{|l|}{ Digestibility (\%) } \\
\hline DM & 59.0 & 61.0 & 59.0 & 55.0 & 0.23 & ns & ns & ns \\
\hline $\mathrm{OM}$ & 63.0 & 65.0 & 63.0 & 58.0 & 0.19 & ns & ns & ns \\
\hline $\mathrm{CP}$ & 48.0 & 54.0 & 53.0 & 49.0 & 0.32 & ns & $\mathrm{ns}$ & ns \\
\hline aNDF & 47.0 & 56.0 & 57.0 & 58.0 & 0.12 & $*$ & $\mathrm{~ns}$ & $\mathrm{~ns}$ \\
\hline
\end{tabular}

${ }^{1} \mathrm{~L}=$ Linear, $\mathrm{Q}=$ Quadratic, $\mathrm{C}=$ Cubic. $* \mathrm{p}<0.05, \mathrm{~ns}=\mathrm{p}>0.05$.

$\mathrm{SEM}=$ Standard error of the mean. $\mathrm{DM}=$ Dry matter. $\mathrm{OM}=$ Oganic matter, $\mathrm{CP}=$ Crude protein, aNDF $=$ Neutral detergent fiber.

and GCC), protein sources (rice bran, brewerys' grain, palm kernel meal) and non-protein nitrogen (urea), had a higher quality in terms of CP (12.0\% DM). The GCC replacement had a higher crude fiber than the $\mathrm{CC}$ based feed and ranged from 16.1 to $68.1 \%$ DM. Rice straw quality was improved in $\mathrm{CP}$ by the urea treatment.

Effect of GCC replacement on feed intake and digestibility

Effect of GCC replacement of CC on total feed intake and nutrient digestibilities is shown in Table 2. Intake of UTS by animals did not differ among the treatments ( $p>0.05$ ), while concentrate DMI was quadratically decreased with the increasing level of GCC replacement ranging from 2.17 to $1.94 \mathrm{~kg} / \mathrm{d}(\mathrm{p}<0.07)$. However, there were no differences among treatments on total DMI by GCC replacement for CC. Apparent digestibility of DM, $\mathrm{OM}$ and $\mathrm{CP}$ were not different among treatments $(\mathrm{p}>0.05)$, while an increasing level of GCC in concentrate linearly increased digestibility of aNDF ranging from 47.0 to $58.0 \%$ $(\mathrm{p}<0.05)$.

\section{Effect of GCC replacement on rumen fermentation and microorganisms}

Ruminal $\mathrm{pH}$ and $\mathrm{NH}_{3}-\mathrm{N}$ were similar among treatments and the values were quite stable at 6.7 to 6.9 and 12.7 to $19.4 \mathrm{mg} / \mathrm{dl}$, respectively (Table 3). However, the replacement of GCC at $100 \%$ showed the highest value of

Table 3. Effect of ground corn cob replacement on ruminal $\mathrm{pH}$, ammonia-nitrogen $\left(\mathrm{NH}_{3}-\mathrm{N}\right)$ and volatile fatty acid (VFA) concentrations in swamp buffalo

\begin{tabular}{|c|c|c|c|c|c|c|c|c|}
\hline \multirow{2}{*}{ Items } & \multicolumn{4}{|c|}{ Ground corn cob replacement (\%) } & \multirow{2}{*}{ SEM } & \multicolumn{3}{|c|}{ Contrast $^{1}$} \\
\hline & 0 & 33 & 67 & 100 & & $\mathrm{~L}$ & Q & $\mathrm{C}$ \\
\hline $\mathrm{pH}$ & 6.8 & 6.7 & 6.8 & 6.9 & 0.07 & ns & ns & $\mathrm{ns}$ \\
\hline $\mathrm{NH}_{3}-\mathrm{N}(\mathrm{mg} / \mathrm{dl})$ & 12.7 & 14.1 & 12.9 & 19.4 & 2.30 & $\mathrm{~ns}$ & ns & ns \\
\hline Total VFA (mmol/L) & 100.6 & 113.4 & 95.3 & 103.5 & 9.96 & ns & ns & ns \\
\hline Acetate & 68.7 & 62.2 & $\begin{array}{c}\text { mol -- } \\
68.8\end{array}$ & 69.7 & 2.04 & ns & ns & $\mathrm{ns}$ \\
\hline Propionate & 19.8 & 23.6 & 19.5 & 16.7 & 1.22 & $*$ & $*$ & $\mathrm{~ns}$ \\
\hline Butyrate & 11.5 & 14.2 & 11.7 & 13.7 & 1.09 & ns & Ns & $\mathrm{ns}$ \\
\hline Acetate:propionate & 3.5 & 2.6 & 3.5 & 4.8 & 1.67 & $*$ & $*$ & $\mathrm{~ns}$ \\
\hline Protozoa $\left(\times 10^{5}\right.$ cell $\left./ \mathrm{ml}\right)$ & 1.25 & 1.60 & 1.45 & 1.31 & 0.15 & ns & ns & ns \\
\hline \multicolumn{9}{|l|}{ Viable bacteria (CFU/ml) } \\
\hline Total $\left(\times 10^{11}\right)$ & 8.4 & 11.0 & 10.9 & 11.3 & 2.0 & ns & ns & ns \\
\hline Cellulolytic $\left(\times 10^{9}\right)$ & 10.5 & 8.6 & 7.6 & 11.1 & 1.8 & $\mathrm{~ns}$ & ns & $\mathrm{ns}$ \\
\hline Proteolytic $\left(\times 10^{8}\right)$ & 7.5 & 12.9 & 13.4 & 13.5 & 2.5 & ns & ns & $\mathrm{ns}$ \\
\hline Amylolytic $\left(\times 10^{8}\right)$ & 12.9 & 7.2 & 16.8 & 19.6 & 6.8 & ns & ns & ns \\
\hline
\end{tabular}

${ }^{1} \mathrm{~L}=$ Linear, $\mathrm{Q}=$ Quadratic, $\mathrm{C}=$ Cubic, ${ }^{*} \mathrm{p}<0.05, \mathrm{~ns}=\mathrm{p}>0.05 . \mathrm{SEM}=$ Standard error of the mean. $\mathrm{CFU}=$ Colony forming unit. 
Table 4. Effect of ground corn cob replacement on microbial protein synthesis in swamp buffalo

\begin{tabular}{|c|c|c|c|c|c|c|c|c|}
\hline \multirow{2}{*}{ Items } & \multicolumn{4}{|c|}{ Ground corn cob replacement (\%) } & \multirow{2}{*}{ SEM } & \multicolumn{3}{|c|}{ Contrast $^{1}$} \\
\hline & 0 & 33 & 67 & 100 & & $\mathrm{~L}$ & Q & $\mathrm{C}$ \\
\hline \multicolumn{9}{|l|}{ Microbial protein synthesis } \\
\hline Microbial N supply (g N/d) & 61.9 & 46.7 & 53.7 & 50.7 & 6.37 & ns & $\mathrm{ns}$ & ns \\
\hline EMNS (g N/kg OMDR) & 22.1 & 16.2 & 22.1 & 18.4 & 2.06 & ns & ns & $\mathrm{ns}$ \\
\hline
\end{tabular}

${ }^{1} \mathrm{~L}=$ Linear, $\mathrm{Q}=$ Quadratic, $\mathrm{C}=$ Cubic. $\mathrm{ns}=\mathrm{p}>0.05$. SEM $=$ Standard error of the mean.

OMDR $=$ Organic matter digested in the rumen. EMNS $=$ Efficiency of microbial $\mathrm{N}$ supply.

$\mathrm{NH}_{3}-\mathrm{N}$ at $19.4 \mathrm{mg} / \mathrm{dl}$. In this study, level of $\mathrm{GCC}$ replacement did not affect on ruminal total VFA, $\mathrm{C} 2$ and $\mathrm{C} 4$ concentrations $(p>0.05)$. In contrast, the proportion of $\mathrm{C} 3$ was quadratically increased with the level of GCC replacement $(\mathrm{p}<0.05)$ and the higher values were in the treatment with replacement of GCC at $33 \%$. As shown, the value of $\mathrm{C} 2$ to $\mathrm{C} 3$ ratio was found to be different among the groups. In addition, ruminal protozoal and viable bacterial populations including total viable bacteria, cellulolytic bacteria, proteolytic bacteria and amylolytic bacteria were not significantly different among treatments $(\mathrm{p}>0.05)$ of $\mathrm{CC}$ and GCC replacement (Table 3).

\section{Effect of GCC replacement on microbial protein} synthesis

Microbial N supply (g N/d) and EMPS (g N/kg OMDR) were ranged from 46.7 to 61.9 , and 16.2 to 22.1, respectively and were similar among all treatments (Table 4). Microbial protein synthesis was not different among GCC replacement levels ( $p>0.05)$, while there was a trend at $67 \%$ replacement level of GCC which showed the highest value of efficiency of microbial protein synthesis. Concentration of PD in animals' urine ranged between 4.1 to $6.5 \mathrm{mmol} / \mathrm{L}$ and varied with time of urination among all treatments (Table 5). At 0 to $8 \mathrm{~h}$-post feeding, PD concentration was quadratically correlated with levels of replacement of GCC $(\mathrm{p}<0.05)$ and continued to increase with GCC replacement levels up to 8 to $16 \mathrm{~h}$-post feeding sampling $(\mathrm{p}<0.05)$. However, at 16 to $24 \mathrm{~h}$-post feeding, PD concentrations were not different among treatments ( $p>0.05)$. In contrast, creatinine concentration was similar in all treatments in all sampling times $(\mathrm{p}>0.05)$.

\section{DISCUSSION}

\section{Chemical composition of diet}

Experimental ingredients were based on local resources especially CC and GCC as the energy sources together with other protein sources. These concentrates were well consumed by the animals during the experimental periods. Crude protein of each concentrate was similar to all treatments. However, the levels of fiber (aNDF and ADF) were higher in concentrate with GCC replacement as an energy source when compared with CC base. This could be due to the higher content of crude fiber of GCC used in this experiment; 67.9 and $48.5 \%$, while CC contain only 50.2 and $43.6 \%$, aNDF and ADF, respectively. These values were similar to those reported by Chanthakhoun and

Table 5. Effect of ground corn cob replacement on purine derivatives and creatinine excretion in swamp buffalo

\begin{tabular}{|c|c|c|c|c|c|c|c|c|}
\hline \multirow{2}{*}{ Items } & \multicolumn{4}{|c|}{ Ground corn cob replacement (\%) } & \multirow{2}{*}{ SEM } & \multicolumn{3}{|c|}{ Contrast $^{1}$} \\
\hline & 0 & 33 & 66 & 100 & & $\mathrm{~L}$ & Q & $\mathrm{C}$ \\
\hline \multicolumn{9}{|c|}{ Purine derivative excretion $(\mathrm{mmol} / \mathrm{L})$} \\
\hline $0-8 \mathrm{~h}$ & 5.2 & 6.1 & 6.5 & 6.2 & 0.35 & ns & $*$ & ns \\
\hline $8-16 \mathrm{~h}$ & 4.9 & 5.4 & 6.1 & 6.1 & 0.57 & $*$ & ns & ns \\
\hline $16-24 \mathrm{~h}$ & 4.8 & 4.1 & 6.0 & 5.0 & 1.03 & ns & ns & $\mathrm{ns}$ \\
\hline Mean & 4.9 & 5.2 & 6.2 & 5.8 & 0.68 & ns & $*$ & $\mathrm{~ns}$ \\
\hline \multicolumn{9}{|c|}{ Creatinine excretion $(\mathrm{mmol} / \mathrm{L})$} \\
\hline $0-8 \mathrm{~h}$ & 21.6 & 21.9 & 21.8 & 21.0 & 0.24 & ns & ns & ns \\
\hline $8-16 \mathrm{~h}$ & 22.2 & 21.4 & 22.0 & 21.8 & 0.16 & ns & ns & ns \\
\hline $16-24 \mathrm{~h}$ & 22.0 & 21.9 & 22.4 & 22.0 & 0.21 & ns & ns & $\mathrm{ns}$ \\
\hline Mean & 21.9 & 21.7 & 22.1 & 21.6 & 0.21 & ns & ns & $\mathrm{ns}$ \\
\hline \multicolumn{9}{|c|}{ Purine derivative to creatinine index } \\
\hline $0-8 \mathrm{~h}$ & 22.2 & 26.0 & 27.6 & 27.5 & 0.19 & ns & 0.07 & ns \\
\hline $8-16 \mathrm{~h}$ & 20.3 & 23.5 & 25.9 & 26.0 & 0.23 & $*$ & $\mathrm{~ns}$ & $\mathrm{~ns}$ \\
\hline $16-24 \mathrm{~h}$ & 23.1 & 17.3 & 24.5 & 21.1 & 0.37 & ns & ns & $\mathrm{ns}$ \\
\hline Mean & 22.2 & 22.3 & 26.0 & 24.9 & 0.31 & $\mathrm{~ns}$ & $*$ & $\mathrm{~ns}$ \\
\hline
\end{tabular}

${ }^{1} \mathrm{~L}=$ Linear, $\mathrm{Q}=$ Quadratic, $\mathrm{C}=$ Cubic. $* \mathrm{p}<0.05, \mathrm{~ns}=\mathrm{p}>0.05, \mathrm{SEM}=$ Standard error of the mean. 
Wanapat (2012). The nutritive value of rice straw was improved by urea treatment, increasing the CP up to $6.8 \%$ and reducing the fiber fraction, 72.3 and $50.3 \%$, aNDF and ADF, respectively. This was consisten with the finding of Wanapat et al. (2009b) who used 5.5\% urea treated rice straw.

\section{Effect of GCC replacement on feed intake and digestibility}

Intake of UTS was found similar in all treatments while intake of concentrate tended to decrease quadratically when the level of GCC was increased. This result may be due to a comparatively low palatability of concentrate containing GCC as an energy source. There is a negative relationship between cell wall constituents (CWS) and voluntary feed intake (Van Soest, 1965). This result was consistent with the finding of Wanapat et al. (2009a) who reported the result of a lower intake with the treatment with GCC mixed concentrate as compared with CC. However, in this study, there was no difference in total feed intake. This indicates that swamp buffalo appear to be able to use high fiber feedstuff as an energy source in concentrate.

There was no effect on DM, OM and CP digestibilities while digestibility of fiber (aNDF) was increased with level of GCC replacement. Han et al. (2003) reported that cellulolytic bacteria in the rumen could be induced by the addition of easily degradable fiber to the fermentation process. Thus, GCC which contained high levels of hemicellulose could support digestion of fiber by cellulolytic bacteria in the rumen of swamp buffalo. As supported by Wanapat et al. (2009a), nutrient digestibilities of buffaloes were not affected by energy source in GCC and $\mathrm{CC}$ concentrate. This result suggested that buffaloes could utilize CC and GCC similarly, regardless of source and level of fiber.

\section{Effect of GCC replacement on rumen fermentation and microorganism}

The $\mathrm{pH}$ ranged from 6.7 to 6.9. Wanapat and Pimpa (1999) suggested that the optimum level of $\mathrm{pH}$ in the rumen should be 6.5 to 7.0 when animals fed mostly on roughages which are in the optimal range for microbial growth. However, the values were higher than the result shown by Wanapat et al. (2009a) ( $\mathrm{pH}=6.3$ to 6.4). Ruminal $\mathrm{pH}$, $\mathrm{NH}_{3}-\mathrm{N}$ and VFA concentrations in the present study were not affected by levels of GCC replacement except the proportion of propionate which quadratically responded. This indicated that GCC can be used as energy source to replace $\mathrm{CC}$ in concentrate mixtures for buffaloes without any negative effect on rumen fermentation. Ruminal replacement of GCC for $\mathrm{CC}$ at $33 \%$ resulted in highest propionic proportion $(23.6 \mathrm{~mol} / 100 \mathrm{~mol})$ and was in normal range (Hungate, 1966). However, this result did not agree with our previous work from Wanapat et al. (2009a) who found that using different energy sources (GCC vs CC) in the concentrate for swamp buffalo did not have any impact on volatile fatty acid production. This may be due to the difference of feed ingredients in which urea was used in the previous work. Moreover, Chanthakhoun and Wanapat (2012) showed similar results to the present study on the VFA concentration in in vitro gas between CC and GCC. $\mathrm{NH}_{3}-\mathrm{N}$ concentration in this experiment was found to range from 12.7 to $19.4 \mathrm{mg} / \mathrm{dl}$ which was similar to the report from Wanapat and Pimpa (1999); 13.6 to $17.6 \mathrm{mg} / \mathrm{dl}$. On the other hand, the $\mathrm{NH}_{3}-\mathrm{N}$ concentration in the present results was higher than the value in the report by Wanapat et al. (2009a) that compared different energy sources between CC and GCC (9.2 to $15.6 \mathrm{mg} / \mathrm{dl})$. The present study and Wanapat et al. (2009a) both found an increasing trend of $\mathrm{NH}_{3}-\mathrm{N}$ concentration using GCC in concentrate mixtures.

Microbial populations in the rumen were not affected by levels of GCC substitution. This result did not agree with previous work (Wanapat et al., 2009a) which found that the population of protozoa was lower in GCC than those in CC fed groups. Moreover, Dennis et al. (1983) found that protozoal populations increased with increases in the concentrate proportion of the diets as non-structural carbohydrate was increased. However, it could be pointed out that protozoa in the rumen of buffalo can adapt to survive under the harsh conditions of this study. Groups of bacteria were not significantly different among treatments, which agreed with our previous work (Wanapat et al., 2009a). However, Russell and Rychlik (2001) found that when ruminants are fed with different rations the microbial ecology will be altered accordingly. This indicates that the bacteria in all groups particularly cellulolytic bacteria in the rumen are capable of surviving the changing of type of carbohydrate or the amount of fiber that buffaloes received from GCC.

\section{Effect of GCC replacement on microbial protein synthesis}

The MPS was not different among GCC replacement levels, although $67 \%$ replacement level showed the highest value. Efficiency of MPS in the present study was lower than in the study of Khampa et al. (2006). This could be due to a difference of animal species (dairy steer and swamp buffalo), and the large proportion of fiber eaten in present experiment ( $70 \%$ of total DMI). However, animals fed on $67 \%$ replacement level of GCC showed higher EMPS than cattle fed on a high level of CC reported by Wanapat and Khampa (2007). Thus, it could be pointed out that GCC can replace up to $100 \%$ of $\mathrm{CC}$ in concentrate diet for swamp buffalo without impact on MPS.

Urinary PD concentration varied among treatments while creatinine concentrations were similar across 
treatments. The present study showed and supported previous work, that buffaloes had lower purine derivative excretion and had greater capability in efficiency of microbial protein supply when compared with cattle (Wanapat et al., 2003). Possible reasons were related to a lower rate of PD absorption in the small intestine and/or recycling of plasma $\mathrm{PD}$ in buffaloes as compared to cattle (Pimpa et al., 2003), while Thanh and Orskov (2006) stated that buffaloes had a slower rate of glomerular filtration which influenced on lower urinary excretion of PD. These results may also be due to variation between rumen fermentation pattern and volumes of urine per time (Cetinkaya et al., 2006). However, this result agreed with the result of Chizzotti et al. (2008) who found that the concentration of creatinine was not affected by either sampling time or feed. Purine derivative to creatinine (PDC) index also quadratically responded with GCC replacement levels. Moreover, both concentration of PD in urine, PDC index and MPS parameters were similarly responding to dietary treatments. It might be pointed that they have relationship between PD excretion, PDC index and MPS of swamp buffalo.

\section{CONCLUSIONS AND RECOMMENDATIONS}

Based on this experiment, it could be concluded that replacement of $\mathrm{CC}$ with $\mathrm{GCC}$ in concentrate had similar effect on feed intake and digestibilities of DM, OM, and CP while aNDF digestibility was linearly increased with the replacement levels. Dietary treatments did not affect rumen fermentation in swamp buffaloes except for the propionic acid proportion which was higher in the $33 \%$ replacement level. Microbial populations and MPS were similar among treatments. Meanwhile, purine derivative concentration and PDC index varied among treatments. It suggested that replacement of $\mathrm{CC}$ by $\mathrm{GCC}$ as an energy source in concentrate mixture for buffaloes revealed similar results to the use of CC. Furthermore, the use of urine spot sampling for urinary PD analysis could be used as an alternative to the total collection method.

\section{ACKNOWLEDGEMENTS}

The authors wish to express their gratitude for the financial support of this research from IAEA/FAO, Vienna and for the use of experimental animals, laboratory facilities provided by Tropical Feed Resources Research and Development Center (TROFREC), Department of Animal Science, Faculty of Agriculture, Khon Kaen University, Thailand.

\section{REFERENCES}

AOAC. 1995. Official method of analysis, 16th ed. Animal Feeds:
Association of Official Analytical Chemists, Virginia, USA, pp. 1-18.

Broderick, G. A. and N. R. Merchen. 1992. Markers for quantifying microbial protein synthesis in the rumen. J. Dairy Sci. 75:2618-2632.

Cetinkaya, N., S. Yaman and N. H. O. Baber. 2006. The use of purine derivatives/ creatinine ratio in spot urine samples as an index of microbial protein supply in Yerli Kara crossbred cattle. Livest. Sci. 100:91-98.

Chanthakhoun, V. and M. Wanapat. 2012. The in vitro gas production and ruminal fermentation of various feeding using rumen liquor from swamp buffalo and cattle. Asian J. Anim. Vet. Adv. 7:54-60.

Chen, X. B. and M. J. Gomes. 1995. Estimation of microbial protein supply to sheep and cattle based on urinary excretion of purine derivatives-an overview of the technical details. Occasional Publication 1992. International Feed Resources Unit, Rowett Research Institude, Aberdeen, United Kingdom. pp. 21-25.

Chen, X. B., D. J. Kyle and E. R. Orskov. 1993. Measurement of allantoin in urine and plasma by high-performance liquid chromatography with pre-column derivatization. J. Chromatogr. 617:241-247.

Chen, X. B., M. C. N. Jayasuriya and H. P. S. Makkar. 2004. Measurement and application of purine derivatives:creatinine ratio in spot urine samples of ruminants. In: Estimation of Microbial Protein Supply in Ruminants Using Urinary Purine Derivatives (Ed. H. P. S. Makkar and X. B. Chen), Kluwer Academic Publishers, Dordrecht. pp. 167-179.

Chizzotti, M. L., S. C. V. Filho, R. F. D. Valadares, F. H. M. Chizzotti and L. O. Tedeschi. 2008. Determination of creatinine excretion and evaluation of spot urine sampling in Holstein cattle. Livest. Sci. 113:218-225.

Dennis, S. M., M. J. Arambel, E. E. Bartle and A. D. Dayton. 1983. Effect of energy concentration and source of nitrogen on numbers and types of rumen protozoa. J. Dairy Sci. 66:12481254.

Depies, K. K. and L. E. Armentano. 1995. Partial replacement of alfalfa fiber with fiber from ground corn cobs or wheat middlings. J. Dairy Sci. 78:1328-1335.

Dewhurst, R. J., D. R. Davies and R. J. Merry. 2000. Microbial protein supply from the rumen. Anim. Feed Sci. Technol. 85: 1-21.

Fries, G. F., C. A. Lassiter, D. M. Steath and J. W. Rust. 1955. A preliminary report on the value of corn cobs and cottonseed hulls for growing dairy heifers. J. Anim. Sci. 14:1203-1210.

Galyean, M. 1989. Laboratory Procedure in Animal Nutrition Research. Department of Animal and Life Science. New Mexico State University, USA. p. 187.

Han, S. O., H. Yukawa, M. Inui and R. H. Doi. 2003. Regulation of expression of cellulosomal cellulase and hemicellulase genes in Clostridium cellulovorans. J. Bacteriol. 185:60676075.

Hawk, P. B., B. L. Oser and W. H. Summerson. 1976. Prac. Physiol. Chem., 14th ed. McGraw Hill Publishing Company Ltd., London.

Hobson, P. N. 1969. Continuous culture of some anaerobic and facutatively anaerobic rumen bacteria. J. Gen. Microbiol. 38: 80-167. 
Hungate, R. E. 1966. The rumen and its microbes. Academic Press. New York and London. p. 533.

Hungate, R. E. 1969. A roll tube method for cultivation of strict anaerobes. In: Methods in Microbiology, edited by Norris (Ed. J. R. Norris and D. W. Ribbons), New York. Academic. pp. 313-117.

IAEA. 1997. Determination of purine derivative in urine. In: Estimation of the rumen microbial protein production from purine derivatives in rumen. Animal Production and Health Section. Vienna, Austria. p. 49.

Khampa, S., M. Wanapat, C. Wachirapakorn, N. Nontaso and M. Wattiaux. 2006. Effects of urea level and sodium DL-malate in concentrate containing high cassava chip on ruminal fermentation efficiency, microbial protein synthesis in lactating dairy cows raised under tropical condition. Asian-Aust. J. Anim. Sci. 19:837-844.

Kiyothong, K. and M. Wanapat. 2004. Growth, hay yield and chemical composition of cassava and Stylo 184 grown under intercropping. Aisan-Aust. J. Anim. Sci. 17:799-807.

Peyton, S. C. and H. R. Conrad. 1982. Corncobs as energy with urea nitrogen in dairy rations. J. Dairy Sci. 65:1465-1471.

Pimpa, O., J. B. Liang, J. Balcells, Z. A. Jelan and N. Abdullah. 2003. Urinary purine derivative excretion in swamp buffaloes after duodenal purine base infusion. Anim. Feed Sci. Technol. 104:191-199.

Promkot, C. and M. Wanapat. 2005. Effect of level of crude protein and use of cottonseed meal in diets containing cassava chips and rice straw for lactating dairy cows. Asian-Aust. J. Anim. Sci. 18:502-511.

Russell, J. B. and J. L. Rychlik. 2001. Factors that alter rumen microbial ecology. Science 292:1119-1122.

Samuel, M., S. Sagathewan, J. Thomas and G. Mathen. 1997. An HPLC method for estimation of volatile fatty acids of ruminal fluid. Indian J. Anim. Sci. 67:805-807.

SAS. 1996. User's guide: Statistic, Version 5. Edition. SAS. Inst Cary, NC, USA.

Siddons, R. C., J. Paradine, D. E. Beever and P. R. Cornell. 1985. Ytterbium acetate as a particulate-phase digesta-flow marker. Br. J. Nutr. 54:509-520.

Singh, M., K. Sharma, N. Dutta, P. Singh, A. K. Verma and U. R. Mehra. 2007. Estimation of rumen microbial protein supply using urinary purine derivatives excretion in crossbred calves fed at different levels of feed intake. J. Anim. Sci. 20:15671574 .
Thanh, Vo Thi Kim and E. R. Orskov. 2006. Causes of differences in urinary excretion of purine derivatives in buffaloes and cattle. J. Anim. Sci. 82:355-358.

Valadares, R. F. D., G. A. Broderick, S. C. Valadares and M. K. Clayton. 1999. Effect of replacing alfalfa silage with high moisture corn on ruminal protein synthesis estimated from excretion of total purine derivatives. J. Dairy Sci. 82:26862696.

Van Soest, P. J. 1965. Symposium on factors influencing the voluntary intake of herbage by ruminants-voluntary intake in relation to chemical composition and digestibility. J. Anim. Sci. 24:834-843.

Van Soest, P. J., J. B. Robertson and B. A. Lewis. 1991. Methods of dietary fiber, neutral detergent fiber and non-starch carbohydrates in relation to animal nutrition. J. Dairy Sci. 74:3583-3597.

Wanapat, M. 1999. Feeding of ruminants in the tropics based on local feed resources, (Khon Kaen Publishing Company Ltd., Khon Kaen, Thailand).

Wanapat, M. 2000. Rumen manipulation to increase the efficiency use of local feed resources and productivity of ruminants in tropics. Asian-Aust. J. Anim. Sci. 13(Suppl.):59-67.

Wanapat, M. and O. Pimpa. 1999. Effect of ruminal $\mathrm{NH}_{3}-\mathrm{N}$ levels on ruminal fermentation, purine derivatives, digestibility and rice straw intake in swamp buffaloes. Asian-Aust. J. Anim. Sci. 12:904-907.

Wanapat, M. and P. Rowlinson. 2007. Nutrition and feeding of swamp buffalo: feed resources and rumen approach. Italian J. Anim. Sci. 6:67-73.

Wanapat, M. and S. Khampa. 2007. Effect of levels of supplementation of concentrate containing high levels of cassava chip on rumen ecology, microbial $\mathrm{N}$ supply and digestibility of nutrients in beef cattle. Asian-Aust. J. Anim. Sci. 20:75-81.

Wanapat, M., N. Nontaso, C. Yuangklang, S. Wora-anu, A. Ngarmsang, C. Wachirapakorn and P. Rowlinson. 2003. Comparative study between swamp buffalo and native cattle in feed digestibility and potential transfer of buffalo rumen digesta into cattle. Asian-Aust. J. Anim. Sci. 16:504-510.

Wanapat, M., R. Pilajun and P. Kongmun. 2009a. Ruminal ecology of swamp buffalo as influenced by dietary sources. Anim. Feed Sci. Technol. 151:205-214.

Wanapat, M., S. Polyorach, K. Boonnop, C. Mapato and A. Cherdthong. 2009b. Effects of treating rice straw with urea or urea and calcium hydroxide upon intake, digestibility, rumen fermentation and milk yield of dairy cows. Livest. Sci. 125: 238-243. 